\title{
Events
}

\section{of Interest}

\section{February 2006}

\section{Mayo Clinic Interactive Surgery Symposium}

Symposium: February 12-17, 2006, Kohala Coast, Hawaii, Hapuna Beach Prince Hotel. Address for information: Registrar, 13400 E Shea Blvd, Scottsdale, AZ 85259 (telephone: 480-301-4580).

\section{CREF 26-The San Diego}

Cardiothoracic Surgery Symposium:

Science and Techniques of Perfusion Conference: February 16-19, 2006, San Diego, California, San Diego Marriott Hotel \& Marina. Address for information: Aligned Management Associates, Inc, 793-A Foothill Blvd, PMB \#119, San Luis Obispo, CA 93405 (telephone: 1-805534-0300; fax: 1-805-534-9030; E-mail: info2006@amainc.com; Web site: www. amainc.com/cref_cardiothoracic.html).

\section{The 16th Utah Pediatric}

Cardiovascular Disease Conference

Meeting: February 18-21, 2006, Snowbird, Utah, Cliff Lodge. Address for information: Becckie Trautman, Pediatric Education Services-3rd Floor, Primary Children's Medical Center, 100 North Medical Dr, Salt Lake City, UT 84113 (telephone: 800-9107262 or 801-588-4060).

Announcements of major meetings and other significant activities must be received at least 8 weeks before the desired month of publication. Information will be limited to title of meeting, date, place, and an address to obtain further information. Send announcements to Pamela W. Fried, Editorial Office, The Journal of Thoracic and Cardiovascular Surgery, MCP Hahnemann University, $245 \mathrm{~N}$ 15th St, Mail Stop 496, Philadelphia, PA 19102-1192. jpower@sapmea.asn.au; Web site: www. sapmea.asn.au/isde.

\section{March 2006}

The Society of Cardiothoracic Surgeons of Great Britain and Ireland

2006 Annual Gereral Meeting: March 1316, 2006, Dublin, Ireland, Citywest Hotel. Program and registration details at www. scts.org. Contact sctsadmin@scts.org.

\section{April 2006}

The American Association for Thoracic Surgery

Annual Meeting: April 29-May 3, 2006, Philadelphia, Pennsylvania, Pennsylvania Convention Center. Address for information: 900 Cummings Center; Suite 221-U, Beverly, MA 01915 (fax: 978-524-8890; E-mail: aats@prri.com; Web site: www. aats.org).

\section{May 2006}

St. Petersburg Russian Federation 55th International Congress of The European Society for Cardiovascular Surgery

Congress: May 11-14 2006, Address for information: Professor Claudio Muneretto, Secretary General, European Society for Cardiovascular Surgery, UDA Cardiochirurgia - Spedali Civili, P.le Spedali Civili 1, 25123 Brescia, Italy (telephone: + 390303996401 fax: + 39030399 6096; Email: munerett@master.cci.unibs.it; Website: http://www.escvsannualcongress. org) Abstract submission deadline: 15 December 2005 
Massachusetts General Hospital-36th Annual Postgraduate Course in General Thoracic Surgery

Course: May 25-26, 2006, Cambridge, Massachusetts, Sonesta Hotel. Address for information: Harvard Medical School, Department of Continuing Education, PO Box 825, Boston, MA 02117-0825 (telephone: 617-384-8600; fax: 617-384-8686; E-mail: hms-cme@hms.harvard.edu; Web site: http://www.cme.hms.harvard.
June 2006

The 14th Annual Meeting of The Asian Society for Cardiovascular Surgery (ASCVS)

Annual Meeting: June 1-3, 2006, Osaka, Japan, Osaka International ConventionCenter. Address for information: Secretariat of the 14th ASCVS, National Cardiovascular Center, 5-7-1 Fujishirodai, Suita, Osaka, 565-8565, Japan (telephone: 81-6-
4863-7290; fax: 81-6-4863-7289; E-mail: ascvs2006@iris.ocn.ne.jp).

\section{The Western Thoracic Surgical} Association

Annual Meeting: June 21-24, 2006, Sun Valley, Idaho, Sun Valley Resort. Address for information: 900 Cummings Center, Suite 221-U, Beverly, MA 01915 (fax: 978-524-8890; E-mail: wtsa@prri.com). 